\title{
Recurrence Indicator
}

National Cancer Institute

\section{Source}

National Cancer Institute. Recurrence Indicator. NCI Thesaurus. Code C93645.

Specifies whether this is a reappearance of an entity, event or activity. 